\title{
CORRELATION ANALYSIS OF NUTRIENT SOIL-PLANT CONTENT AND BUD TAKE SUCCESS IN Hevea brasiliensis MUELL. ARG. IN ACIDIC SOIL OF SOUTH EASTERN NIGERIA
}

\author{
E.G.O. Ogidi*, I. K. Okore, and J.C. Dike \\ Crop Improvement and Biotechnology Programme, Rubber Research Institute of Nigeria, Sub- Station Akwete, P.M.B. 02, Abia State, Nigeria.
}

Received - May 19, 2017; Revision - June 18, 2017; Accepted - December 14, 2017

Available Online - February 20, 2018

DOI: http://dx.doi.org/10.18006/2018.6(1).116.123

KEYWORDS
Hevea brasiliensis
Bud take success
Bud stick
Correlation
Nutrient content
Principal component analysis

\begin{abstract}
Numerical analysis of some quantitative nutrient soil-plant content and bud take in Hevea brasiliensis (HB) were carried out in 2014 and 2015 at Rubber Research Institute of Nigeria Sub-station Akwete, Abia State, Nigeria. Further, effect of different fertilizer doses and bud wood age on soil - plant nutrient absorption and Hevea budding success was also investigated during this study. Three doses of N.P.K (20:10:10) fertilizer $(0,100$, and $150 \mathrm{~kg} / \mathrm{ha})$ were applied to five bud wood garden of different ages $(2$, $5,10,15$ and 20 years) in a factorial pattern with three replicates in late October 2014. Budding activities and transplanting were carried out in 2015. Result of study revealed that bud wood age and NPK fertilizer significantly ( $\mathrm{P}<0.05)$ increased bud stick length, bud take percentage and sprouting. Significant positive correlations $(\mathrm{P}<0.01)$ were reported between soil calcium and magnesium, soil organic matter and total nitrogen, available phosphorous, exchangeable potassium; leaf nitrogen, calcium and phosphorous contents. Percentage bud take showed positive effect with soil organic carbon, total nitrogen, exchangeable calcium, leaf calcium and nitrogen content. Four Principal components (PC) had eigen values greater than one and contributed $99.6 \%$ of the total variation among the studied parameters. PC1 contributed 69.30\%, whereas PC2, PC3 and PC4 contributed $14.84 \%, 9.11 \%$ and 6.35
\end{abstract}

* Corresponding author

E-mail: ogidyke@yahoo.com (E.G.O. Ogidi)

Peer review under responsibility of Journal of Experimental Biology and Agricultural Sciences.

Production and Hosting by Horizon Publisher India [HPI] (http://www.horizonpublisherindia.in/).

All rights reserved.
All the article published by Journal of Experimental Biology and Agricultural Sciences is licensed under a Creative Commons Attribution-NonCommercial 4.0 International License Based on a work at www.jebas.org.

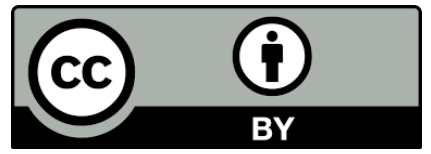


$\%$ respectively of the total variation. Accordingly, PC1 was loaded with soil organic carbon, total nitrogen, available phosphorous, exchangeable potassium, calcium, magnesium, leaf nitrogen and calcium contents and were most discriminative. Hence, appropriate selection based on PC1 parameters will enhance Hevea brasiliensis budding programme in southeastern Nigeria.

\section{Introduction}

Natural rubber (Hevea brasiliensis) is an important plantation crop that is grown in over 10.3 million hectares globally (International Rubber Study Group, 2012). Along with its ecological importance, rubber is mainly grown in the humid tropical areas of Nigeria where the soil is highly weathered, characterized by rapid organic matter decomposition (Awodun et al., 2007) Strongly acid with low exchangeable base cations and available phosphorous $(\mathrm{P})$ as well as high iron $(\mathrm{Fe})$ and manganese (Mn) concentration (Waizah et al., 2011; Oku et al., 2012; Suchartgul et al., 2012). Soil is a reservoir of plant nutrients and greatly varies with their distribution in time and space due to changes in chemical and physical characteristics (Awe et al., 2007). The productivity depends on the equilibrium between organic input supply and decomposition. Plant growth and development depend largely on the combination and concentration of mineral nutrients available in the soil and this is greatly influenced by root adaptations. For plants to maintain nutrient homeostasis, nutrient uptake and respond to changes in the soil and within the plant must be regulated (Kumar et al., 2017). Essential nutrients for plant growth could either be from organic or inorganic source or their combination. The inorganic sources involved the use of fertilizers. However, organic amendments decompose very rapidly under hot and warm humid tropical conditions and require repeatedly application at short intervals to sustain soil productivity (Jenkinson \& Ayanaba, 1977; Dharmakeerthi et al., 2012).To improve and obtain sustainable Hevea bud stick and latex yield, proper management of essential nutrients is required. Soil and plant nutrient content analysis have often been used for nutrient diagnosis based on the hypothesis that there is relationships between plant growth rates (yield) and its nutrient content (Marschner, 1997).

Soil nutrient management with inorganic fertilizer or integrated nutrient application in rubber supporting soils in terms of improved vigour and establishment, latex yield, dry rubber content of latex and soil nutrient conservation have been reported (Okore et al., 2007; Esekhade et al., 2013; Abraham et al., 2015; Alle et al., 2015; Okore et al., 2016). Previously conducted studies revealed significant effects of organic manure on the growth and nutrient cycling of Hevea (Tolentino, 2010; Waizah et al., 2011; Dharmakeerthi et al., 2012; Damrongrak et al., 2015).
Various researchers have utilized various available numerical analysis methods like multivariate technique; Cluster Analysis (CA), Discriminant Analysis (DA), Principal component analysis (PCA) for characterizing distinct agronomic characteristics and soil relationships in various crops such as rubber (Alika, 1991; Gouvêa et al., 2010; Omokhafe \& Alika,2000), rice (Nassir, 2002; Adebisi et al., 2013), melon (Idehen et al., 2007), wheat (Habibpour et al., 2012), African yam bean (Nwofia et al., 2014) and in soil properties characterization (Nageswara \& Jose, 2002; Campbell, 2004; Couto et al., 2006; Iwara et al., 2011; Edokpayi et al., 2015).

Principal Component Analysis is a method that reduces data, exhibits the association between two or more parameters of a crop dividing the total variance of the original parameters into limited number of uncorrelated new variables. The reduction leads to linear transformation of the original variables into a new set of noncorrelated variables, known as Principal Components (PCs) (Wiley, 1981). The analysis also helps to identify the genetic distance between crop genotypes (Aremu et al., 2007). PCs are orthogonal and independent of each other revealing different properties of the original data as may be interpreted independently. According to Mohammadi \& Prasanna (2003), total variation of the original data could be partitioned into components that are cumulative in nature. The purpose of this study is to investigate the effect of fertilizer and bud wood age on bud take of Hevea brasiliensis as well as assess their effects on the soil and leaf nutrient contents of the crop.

\section{Materials and Methods}

The field experiment was conducted between 2014 and 2015 Hevea brasiliensis bud wood garden cut back and budding seasons at the Rubber Research Institute of Nigeria Substation Akwete, Abia State (lat. $4^{\circ} 50^{\prime}$ and $4^{\circ} \quad 65^{\prime} \mathrm{N}$ and Long.70 $00^{\prime}$ and $\left.7019^{\prime} \mathrm{E}\right)$. The climate is humid tropics with an average precipitation of $2,163 \mathrm{~mm}$. The temperature is generally high ranging from $33-34^{\circ} \mathrm{C}$ as the maximum and $28-29^{\circ} \mathrm{C}$ as the minimum. It has two distinct seasons (rainy season- March / April to October and dry season- November to March). The soils of Akwete are mainly coastal plain acid sands of Niger Delta Basin derived from unconsolidated sedimentary deposits of Miocene Pleistocene periods (ILACO- NEDECO, 1966; Kamalu et al., 2014). 
The treatments comprised a $5 \times 3$ factorial combinations arranged in a randomized complete block design with three replications. The first factor consisted of five bud wood garden of different ages (2, 5, 10, 15 and 20 years) while the second factor consisted of three doses of NPK 20:10:10 fertilizer (NPK) (0, 100 and 150 $\mathrm{kg} / \mathrm{ha}$ ). The fertilizer was applied in late October 2014 after cutting back the bud woods, while budding was carried out in 2015. The budded stumps were transplanted to the field at $0.5 \mathrm{~m} \mathrm{x}$ $0.5 \mathrm{~m}$ spacing. All the standard agronomic practices for bud wood garden establishment and management were adopted.

Composite soil ( $0-15 \mathrm{~cm}$ depth) and plant tissues were collected from each treatment in three replicates for chemical properties. Prior to analyses, soil samples were air-dried, grounded to pass through a $2 \mathrm{~mm}$ sieve and analyzed for soil $\mathrm{pH}$ with a digital $\mathrm{pH}$ meter in distilled water at soil / water (1:1). Bray P-1 extractant was used to extract available $\mathrm{P}$ and measured by the Murphy blue coloration and determined on a spectronic 20 at 882um.Exchangeable Potassium $\left(\mathrm{K}^{+}\right)$, Magnesium $\left(\mathrm{Mg}^{2+}\right)$, and Calcium $\left(\mathrm{Ca}^{2+}\right)$ were extracted with neutral normal ammonium acetate. $\mathrm{K}^{+}, \mathrm{Ca}^{2+}$ were determined by flame photometer while $\mathrm{Mg}^{2+}$ was by atomic absorption spectrophotometer. Soil organic carbon (SOC) was determined by wet oxidation method and total nitrogen (TN) by the micro-kjeldahl techniques (AOAC, 1990). The leaf tissues were prepared by washing, oven dried for 48 hours at $70^{\circ} \mathrm{C}$ and milled. The tissues were analyzed for $\mathrm{N}$ content using micro - Kjeldahl method and the $\mathrm{P}, \mathrm{Ca}, \mathrm{Mg}$ and $\mathrm{K}$ contents determined using wet oxidation method (IITA,1979). Parameters such as bud stick length $(\mathrm{cm})$, percentage bud take and sprouting were collected manually by physical counting.

The data generated were subjected to Principal component analysis (PCA) according to PRINCOMP procedure using SAS software (SAS, 1996) to identify parameters that could improve budding of $H$. brasiliensis. Pearson correlations were determined to examine inter- character relationships among the parameters using the SPSS version 16.0 (2004) following the procedure outlined by Miller et al., (1958). The degree of significance of the correlation coefficients of the parameters was tested according to the standard table (Snedecor \& Cochran, 1980).

\section{Results and Discussion}

The study revealed that bud wood ages and fertilizer doses significantly $(\mathrm{P}<0.05)$ influenced the produced bud stick length (Table 1). Among the various NPK application dose, $100 \mathrm{~kg} / \mathrm{ha}$ of NPK fertilizer significantly produced the longest bud stick $(166.33 \mathrm{~cm})$ as compared to the other doses. Further, in case of bud wood garden age, bud sticks produced from 15 year bud wood garden were longer $(199.96 \mathrm{~cm})$ but statistically not different with bud stick obtained from 10 year old bud wood
$(166.69 \mathrm{~cm})$. The interaction between the bud wood garden and fertilizer doses was not significant.

Application of $150 \mathrm{~kg} / \mathrm{ha}$ NPK fertilizer significantly $(\mathrm{P}<0.05)$ increased the percentage bud take $(68.78 \%)$ (Table 2$)$. This value was higher than 0 and $100 \mathrm{~kg} / \mathrm{ha}$ NPK fertilizer doses by $23.11 \%$ and $17.41 \%$, respectively. 10-year old bud wood significantly recorded the highest percentage bud take $(72.22 \%)$. While lowest percentage bud take of $53.49 \%, 54.67 \%$ and $55.51 \%$ were obtained with 2, 5 and 20 years bud wood, respectively. The interaction of bud wood ages and NPK fertilizer doses on percentage bud take were significant and the highest value of $81.82 \%$ was observed with the application of $150 \mathrm{~kg} / \mathrm{ha}$ NPK fertilizer on 5 years bud wood garden.

Contrary to percentage bud take, $\%$ sprouting was not significantly $(\mathrm{P}>0.05)$ affected by NPKF doses, with $100 \mathrm{~kg} / \mathrm{ha}$

Table 1 Effect of $H$. brasiliensis bud wood garden age and NPK fertilizer doses on bud stick length $(\mathrm{cm})$

\begin{tabular}{|ccccc|}
\hline \multicolumn{5}{c}{ fertilizer doses on bud stick length $(\mathrm{cm})$} \\
\hline BA & \multicolumn{4}{c|}{ FD doses (kg/ha) } \\
(Years $)$ & 0 & 100 & 150 & Mean \\
\hline 2 & 110.67 & 173.33 & 145.33 & 143.12 \\
\hline 5 & 123.00 & 158.30 & 140.00 & 140.43 \\
\hline 10 & 212.00 & 150.33 & 137.40 & 166.59 \\
\hline 15 & 155.83 & 165.38 & 188.67 & 199.96 \\
\hline 20 & 121.67 & 184.33 & 131.64 & 147.55 \\
\hline Mean & 144.64 & 166.33 & 149.61 & \\
\hline
\end{tabular}

LSD (0.05): $\mathrm{BA}=45.06, \mathrm{FD}=20.71, \mathrm{BA} \times \mathrm{FD}=\mathrm{NS}, \mathrm{BA}=\mathrm{Bud}$ wood age, FD $=$ Fertilizer dose, $\mathrm{BA} \times \mathrm{FD}=$ Bud wood age and fertilizer doses interaction

Table 2 Effect of bud wood garden age and NPK fertilizer doses on percentage bud take and percentage sprouting of $\mathrm{H}$. brasiliensis

\begin{tabular}{|c|c|c|c|c|c|c|c|c|}
\hline \multirow{3}{*}{$\begin{array}{c}\text { BA } \\
\text { (Years) }\end{array}$} & \multicolumn{8}{|c|}{ FD doses $(\mathrm{kg} / \mathrm{ha})$} \\
\hline & \multicolumn{4}{|c|}{$\begin{array}{l}\text { Percentage Bud take } \\
\text { (28 DAB) }\end{array}$} & \multicolumn{4}{|c|}{$\begin{array}{l}\text { Percentage sprouting } \\
\text { (90 DAT) }\end{array}$} \\
\hline & 0 & 100 & 150 & Mean & 0 & 100 & 150 & Mean \\
\hline 2 & 53.35 & 53.55 & 53.77 & 53.49 & 61.70 & 58.30 & 41.70 & 53.90 \\
\hline 5 & 32.24 & 50.00 & 81.82 & 54.67 & 68.30 & 66.70 & 50.00 & 61.70 \\
\hline 10 & 66.67 & 70.00 & 80.00 & 72.22 & 75.00 & 83.30 & 75.00 & 77.80 \\
\hline 15 & 49.67 & 60.00 & 75.00 & 61.56 & 25.00 & 50.00 & 33.30 & 36.10 \\
\hline 20 & 62.50 & 50.70 & 53.33 & 55.51 & 58.30 & 33.30 & 25.00 & 38.90 \\
\hline Mean & 52.80 & 56.81 & 68.78 & & 57.70 & 58.30 & 45.00 & \\
\hline
\end{tabular}


NPKF giving the highest number of percentage sprouted budded stumps $(\mathrm{P}>0.05)$. This value was $1.03 \%$ and $22.8 \%$ higher than those of 0 and $150 \mathrm{~kg} / \mathrm{ha}$ of NPKF respectively. 10 year old bud wood garden produced the highest percentage sprouting value of $77.8 \%$ relative to other bud wood ages. The general increase in bud stick length and \% bud take with corresponding increase in bud wood age revealed the effect of root length in nutrient absorption. This is however in contrast to the reports of Ishfaq et al. (2012) in sweet orange and Samish \& Gur (1962) in avocado with different rootstock ages.

Combined Pearson's correlation analysis of soil and leaf nutrient parameters (Table 3) showed that except leaf potassium that showed negative and non-significant $(\mathrm{P}>0.05)$ relationship with leaf calcium; soil $\mathrm{pH}$, soil organic carbon, total nitrogen, available phosphorous, exchangeable potassium, calcium, magnesium, leaf nitrogen; leaf phosphorous had positively higher significant ( $\mathrm{P}<0.01)$ relationship with leaf calcium. Soil $\mathrm{pH}$, soil organic carbon, total nitrogen, available phosphorus, exchangeable potassium, calcium and magnesium showed a highly positive significant $(\mathrm{P}<0.01)$ correlation with leaf nitrogen. Similar positive relationship were reported by Kumar et al. (2017) in mustard. Leaf potassium exhibited negative and non - significant ( $\mathrm{P}>0.05)$ correlation with soil $\mathrm{pH}$, total nitrogen, available phosphorous, $\mathrm{K}^{+}$and $\mathrm{Ca}^{2+}$ and leaf nitrogen.

Similarly, leaf magnesium was negatively correlated with soil organic carbon $(r=-.305)$, total nitrogen $(r=-.425)$, available phosphorous $(\mathrm{r}=-.220), \mathrm{K}^{+}(=-.194), \mathrm{Ca}^{2+}(\mathrm{r}=-.286), \mathrm{Mg}^{2+}$ $(\mathrm{r}=-.323)$, leaf nitrogen $(\mathrm{r}=-.349)$ and leaf potassium $(\mathrm{r}=-.240)$. Furthermore, soil $\mathrm{pH}$ had a significantly positive $(\mathrm{P}<0.01)$ correlation with soil organic carbon $(r=.970)$, total nitrogen $(\mathrm{r}=.961)$, available phosphorous $(\mathrm{r}=.945)$ and the exchangeable bases measured; leaf phosphorous $(r=.737)$, leaf calcium $(\mathrm{r}=.810)$ except leaf potassium and leaf magnesium. $\mathrm{Mg}^{2+}$ and $\mathrm{Ca}^{2+}$ were highly significant $(\mathrm{P}=0.01)$ and positively correlated with soil organic carbon $(r=.989)$, total nitrogen $(r=.978)$, available phosphorous $(\mathrm{r}=.979), \mathrm{K}^{+}(\mathrm{r}=.978), \mathrm{Ca}^{2+}(\mathrm{r}=.990)$ and soil organic carbon $(\mathrm{r}=.985)$, soil nitrogen $(.976)$, soil phosphorous $(r=.956), K^{+}(r=.967)$ respectively.

Significant and positive relationship existed between soil potassium and soil phosphorous with soil organic carbon $(\mathrm{r}=.989)$, soil nitrogen $(\mathrm{r}=.951)$, soil phosphorous $(\mathrm{r}=.994)$ and soil organic carbon $(r=.981)$, soil nitrogen $(r=.941)$ respectively. The significant and positive correlation between soil phosphorous and soil organic carbon $\left(\mathrm{r}=.980^{* *}\right)$ indicates that the availability of soil phosphorous is influenced by the content of organic carbon and soil pH (Kavitha \& Sujatha, 2015). The strong positive and significant correlation observed amongst soil parameters corroborates previous works by Corley \& Tinker (2009); Kavitha \& Sujatha (2015), Abraham et al. (2015) in their reports on soil fertility evaluation. Also, Osayande et al. (2014) observed numerous interactions where one ion or nutrient interferes with or competes with the uptake and utilization of other nutrient by plants due to dynamics in soil $\mathrm{pH}$. The strong relation between

Table3 Combined Pearson's correlation between soil and leaf chemical properties across the bud wood ages

\begin{tabular}{|c|c|c|c|c|c|c|c|c|c|c|c|c|}
\hline & SpH & SOC & $\mathbf{T N}$ & AvP & SK & SCa & SMg & $\mathbf{L N}$ & $\mathbf{L P}$ & LK & LCa & LMg \\
\hline SpH & 1 & & & & & & & & & & & \\
\hline SOC & $.970 * *$ & 1 & & & & & & & & & & \\
\hline TN & $.961 * *$ & $.980 * *$ & 1 & & & & & & & & & \\
\hline AvP & $.945^{* *}$ & $.980 *$ & $.941 * *$ & 1 & & & & & & & & \\
\hline SK & $.965^{* *}$ & $.981 * *$ & $.951 * *$ & $.994 * *$ & 1 & & & & & & & \\
\hline SCa & $.970 * *$ & $.985^{* *}$ & $.976^{* * *}$ & $.956 * *$ & $.967 * *$ & 1 & & & & & & \\
\hline SMg & $.959^{* *}$ & $.989 * *$ & $.978 * *$ & $.979 * *$ & $.978 * *$ & $.990 * *$ & 1 & & & & & \\
\hline $\mathbf{L N}$ & $.966^{* * *}$ & $.990 * *$ & $986^{* *}$ & $.963 * *$ & $.969 * *$ & $.996^{* * *}$ & $.996 * *$ & 1 & & & & \\
\hline $\mathbf{L P}$ & $.737 \mathrm{~ns}$ & $.821^{* * *}$ & $-.828 * *$ & $.860 * *$ & $.812 * *$ & $.777 * *$ & $.852 * *$ & $.822 * *$ & 1 & & & \\
\hline LK & $-.420 \mathrm{~ns}$ & $.333 \mathrm{~ns}$ & $-.313 \mathrm{~ns}$ & $-.212 \mathrm{~ns}$ & $-.308 \mathrm{~ns}$ & $-.372 \mathrm{~ns}$ & $.252 \mathrm{~ns}$ & $-.316 \mathrm{~ns}$ & $.251 \mathrm{~ns}$ & 1 & & \\
\hline LCa & $.810^{* * *}$ & $.859^{* * *}$ & $.919^{* * *}$ & $.785^{* * *}$ & $.785^{* *}$ & $.858 * *$ & $.867 * *$ & $.867 * *$ & $.822 * *$ & $-.176 \mathrm{~ns}$ & 1 & \\
\hline LMg & -.232 & $-.305 \mathrm{~ns}$ & $-.425 \mathrm{~ns}$ & $-.220 \mathrm{~ns}$ & $-.194 \mathrm{~ns}$ & $-.286 \mathrm{~ns}$ & $-.323 \mathrm{~ns}$ & $-.349 \mathrm{~ns}$ & $-.550 *$ & $-.240 \mathrm{~ns}$ & $-.732 * *$ & 1 \\
\hline
\end{tabular}

**, significant at $1 \%$ level; *, significant at $5 \%$ level; ns, non-significant; SpH, Soil pH; SOC, Soil organic carbon; TN, Total nitrogen; AvP, Available phosphorous; SK, Exchangeable potassium; SCa, Exchangeable calcium; SMg, Exchangeable magnesium; LN, Leaf nitrogen; LP, Leaf phosphorous; LK, Leaf potassium; LCa, Leaf calcium; LMg, Leaf magnesium.

Journal of Experimental Biology and Agriculture Science http://www.jebas.org 
potassium and organic carbon of the soil is line with the reports of Chauhan (2001) and Kavitha \& Sujatha (2015). According to Kamalu et al. (2014) major problem associated with acidity of soils is the conversion (fixation) of added nutrients to unavailable forms. Furthermore, Tisdale et al. (1993) reported that decomposition of organic matter produces humus, which protects phosphorus against fixation. Percent Bud take with leaf nutrient and soil contents relationship as presented in Table 4 indicates that percent bud take had a positive association $(\mathrm{P}>0.05)$ with leaf nitrogen $(r=.279)$ and leaf calcium $(r=.544 *)$ and negatively significant $(\mathrm{P}=0.05)$ associated with leaf potassium $(\mathrm{r}$ $=-.532)$ and leaf magnesium $(\mathrm{r}=-.586)$. The result further indicated that $\%$ bud take had positive but non-significant $(\mathrm{P}>$ 0.05) relationship with soil potential of hydrogen, soil organic carbon, total nitrogen, available phosphorous and the exchangeable bases (potassium, calcium and magnesium).This demonstrates the importance of these nutrient in actualizing substantial success in the production of certified Hevea planting materials as reported by Okore et al. (2007).

Table 4 Pearson's correlation between leaf, soil nutrient parameters and bud take in $H$. brasiliensis

\begin{tabular}{|cccc|}
\hline Parameters & $\mathrm{R}$ & Parameters & $\mathrm{R}$ \\
\hline$\% \mathrm{BT}$ & 1 & $\mathrm{BT}$ & 1 \\
\hline $\mathrm{LN}$ & .279 & $\mathrm{SpH}$ & .255 \\
\hline $\mathrm{LP}$ & -.018 & $\mathrm{SOC}$ & .216 \\
\hline $\mathrm{LK}$ & $-.532^{*}$ & $\mathrm{SN}$ & .336 \\
\hline $\mathrm{LCa}$ & $.544^{*}$ & $\mathrm{SP}$ & .029 \\
\hline $\mathrm{LMg}$ & $-.586^{*}$ & $\mathrm{SK}$ & .087 \\
\hline & & $\mathrm{SCa}$ & .281 \\
\hline & & $\mathrm{SMg}$ & .197 \\
\hline $\begin{array}{l}R=\text { Correlation coefficients, } \\
\text { probability }\end{array}$ & & &
\end{tabular}

The principal component analysis (PCA) (Table 5) showed the relationship between the 13 studied parameters and their latent root values as a basis of identification of variation and classification. Accordingly, coefficients equal to or greater than 0.3 have large effect to be considered important (Raji, 2002). While parameters having less than 0.2 coefficient value are considered to be of no effect to the over-all variation as observed in this study (Idehen et al., 2007; Yada et al., 2010).

The PCA grouped the parameters to orthogonal components with the first four groups having eigen values greater than unity and together accounting for $99.6 \%$ of the total variability; with PC1, PC2, PC3 and PC4 contributing 69.30, 14.84, 9.11 and $6.35 \%$ respectively of the total percentage variability. This signifies the nutrients influence on budding performance. The most contributing parameters to bud take success in PC1were soil $\mathrm{pH}$ (0.26), soil organic carbon (0.27), total nitrogen (0.27), available phosphorous (0.27), exchangeable potassium (0.27), calcium (0.27) and magnesium (0.28) and leaf nitrogen (0.27). Similar results were obtained by Edokpayi et al. (2015) in describing the nutrient status of soils supporting oil palm in southern Nigeria. While in PC2, contributions were manifested through leaf calcium (0.28). In PC3, the most important parameters to percent bud-take (budding success) were leaf phosphorus (-0.41), leaf potassium $(-0.65)$ and leaf magnesium and leaf potassium $(-0.24)$ in PC4

Table 5 Principal component analysis of soil and leaf chemical parameters and bud take in $H$. brasiliensis grown on acid sand soil

\begin{tabular}{|ccccc|}
\hline Parameters & PC1 & PC2 & PC3 & PC4 \\
\hline$\%$ B T & 0.05150 & 0.55477 & 0.18132 & -0.18137 \\
\hline SpH & 0.26344 & 0.04394 & 0.10919 & 0.16168 \\
\hline SOC & 0.26921 & 0.04213 & 0.01777 & 0.17667 \\
\hline TN & 0.26695 & 0.11648 & -0.01555 & 0.10256 \\
\hline AVP & 0.26748 & -0.06442 & -0.03468 & 0.18990 \\
\hline K+ & 0.26658 & -0.03608 & 0.03016 & 0.21769 \\
\hline Ca ${ }^{+2}$ & 0.27259 & 0.05119 & 0.08020 & 0.04137 \\
\hline Mg ${ }^{+2}$ & 0.27462 & 0.01782 & -0.01380 & 0.05885 \\
\hline LN & 0.27328 & 0.06368 & 0.01972 & 0.05556 \\
\hline LP & 0.23214 & -0.02276 & -0.40483 & 0.06095 \\
\hline LK & -0.06605 & -0.21513 & -0.65281 & -0.24420 \\
\hline LCa & 0.23444 & 0.28057 & -0.17536 & -0.00360 \\
\hline LMg & -0.08266 & -0.21513 & -0.65281 & 0.10324 \\
\hline Latent roots & 13.166 & 2.820 & 1.730 & 1.207 \\
\hline $\begin{array}{c}\text { Percentage } \\
\text { variation }\end{array}$ & 69.30 & 14.84 & 9.11 & 6.35 \\
\hline Cumulative $\%$ & 69.30 & 84.14 & 93.25 & 99.6 \\
\hline
\end{tabular}

\section{Conclusion}

The study showed that fertilizer application and bud wood garden age significantly increased the bud stick length and $\%$ bud take. Soil organic carbon was positively and highly correlated with soil nitrogen, phosphorous, potassium, calcium, magnesium, leaf nitrogen and leaf calcium. These parameters as further identified in PC1, have potentials in enhancing budding programme in Hevea multiplication. Consequently, soil nutrient management should be of utmost importance for successful annual production of certified Hevea brasiliensis budding materials, irrespective of the bud wood garden age. 


\section{Acknowledgements}

The authors are grateful to the management of Rubber Research Institute of Nigeria for providing financial support to carry out this research work and staff of the Research / Nursery unit of the Akwete Sub-Station for their assistance with field work.

\section{Conflict of interest}

The authors have no conflict of interest in the course of this study.

\section{References}

Abraham J, Joseph K, Joseph P (2015) Effect of integrated nutrient management on soil quality and growth of Hevea brasiliensis during the immature phase. Rubber Science 28: 159167.

Adebisi MA, Okelola, FS, Ajala MO, Kehinde TO, Daniel IO, Ajani OO (2013) Evaluation of variations in seed vigour characters of West African rice (Oryza sativa L.) genotypes using multivariate technique. American Journal of Plant Science 4: 56363.

Alika JE (1991) Principal component analysis of variations pattern among sixteen Hevea clones. Nigerian Journal of Agricultural Science 6: 20-24.

Alle JY, Dick EA, Soumahian EF, Olaye RG, kebi JZ, Obouayea $S$ (2015) Effect of mineral fertilizer on agro physiological parameters and economic viability of clone PB 253 of Heveabrasiliensis in the region of $\mathrm{G} \mathrm{O}$ in SW. Coted'voire. Journal of Animal and Plant Sciences 24: 3768 - 3780.

AOAC (1990) Official methods of analysis $15^{\text {th }}$ edition.Association of official analytical chemists Washington, D.C. USA.

Aremu CO, Ariyo OJ, Adewale BD (2007) Assessment of selection techniques in genotype $\mathrm{x}$ environment interaction in cowpea (Vigna unguiculata L.) Walp. African Journal of Agriculture Research 2: $352-355$.

Awe OA, Thogong TK, Nze'e SY, Adegboye MA (2007) A survey of soil fertility management technologies used by small holders in Jos Plateau. In: Olufaji OO (Ed), Reviving Agriculture for sustainable natural growth and stable democracy. Proceedings of the 41st Annual Conference of Agricultural society of Nigeria (ASN) held at IAR, Samaru, ABU Zaria, Nigeria $22^{\text {nd }}-26^{\text {th }}$ October, 2007.

Awodun MA, Ojeniyi SO, Adeboye A, Odedina SA (2007) Effect of oil palm bunch refuse ash on soil and plant nutrient composition and yield of maize. American Eurasian Journal of Sustainable Agriculture 1: 50 - 54.

Campbell S (2004) Discriminant analysis of heavy metal concentrations in the soil of St.John's New found land. Available on

http://www.mun.ca/biology/schneider/b4605/GradProj/StacyCam pbellProj04.pdf access on 29th April, 2017.

Chauhan JS (2001) Fertility status of soils of Bilra panchayathsamiti of Jodhpur district (Rajasthan). M.Sc. (Ag.) thesis submitted to MPUAT, Udaipur, Rajasthan, India.

Corley RHV, Tinker PB (2009) The Oil palm, 4th Edition. UK Blackwell Science Ltd. Oxford.

Couto EG, CuntaCaitianunes da (2006) Application of Multivariate analysis to identify soil landscapes in the Pantanal of MatoGrosso - Brazil, a poster presentation at the symposium organized by WCSS held in Thailand, $14^{\text {th }}-21^{\text {st }}$ August, 2002.

Damrongrak I, Onthong J, Nilnond C (2015) Effect of fertilizer and dolomite applications on growth and yield of tapping rubber trees. Songklanakarin Journal of Science and Technology 37: 643650.

Dharmakeerthi RS, Chandrasiri JAS, Edirimanne VU (2012) Effect of rubber wood biochar on nutrition and growth of nursery plants established in an ultisol. Springer plus 1:1-13.

Edokpayi AA, Osayande PE, Ikuenobe CE, Aghimien AE (2015) Multivariate analysis of soils under oil palm cultivation in Nigeria. Nigerian Journal of Agriculture Food and Environment 11: $97-102$.

Esekhade TU, Okore IK, Ogidi EGO, Arasowan J (2013) Effect of weeding frequency and fertilizer

rates on the Growth performance and budding successes of Hevea rootstock seedling in a humid forest area of south eastern Nigeria. International Journal of Agriculture and Rural Development16: 1421-1424.

Gouvêa LRL, Rubiano LB, Chioratto AF, Zucchi M, Gonçalves PS (2010) Genetic divergence of rubber tree estimated by multivariate techniques and microsatellite markers. Genetics and Molecular Biology 33: 308-318.

Habibpour M, Ahmadizadeh M, Shahbazi H (2012) Assessment of relationship between agro - morphological traits and grain yield in bread wheat genotypes under drought stress condition. African Journal of Biotechnology 11:8698 - 8704. 
Idehen EO, Kehinde OB, Ariyo OJ (2007) Numerical analysis of variation among Nigerian accessions of 'Egusi' Melon (Citrullus lanatus (Thunb.) Matsum \& Nakai). Journal of American Science 3: 7-15.

ILACO NEDECO (1966) Report on the soil investigations in the Niger Delta special areas. The Hague special areas Aruhem, The Hague, Netherlands.

International Institute of Tropical Agriculture (1979) Laboratory manual for soil and plant analysis. Manual series 7, IITA, Ibadan.

International Rubber Study Group (2012). Rubber Statistical Bulletin 52:7-9.

Ishfaq M, Abbas RM, Nasir IA (2012) Effect of budwood age, budding height and stock looping, on bud take in sweet orange (Citrus sinensis L.) var pine apple. Global Advanced Research Journal of Agricultural Science 1:275-278.

Iwara AI, Ogundele FO, Ibor UW (2011) Multivariate Analysis of Soil - Vegetation Interrelationships in a South - Southern Secondary forest of Nigeria. International Journal of Biology 3 : $73-82$.

Jenkinson DS, Ayanaba A (1977) Decomposition of carbon-14 labeled plant material under tropical conditions. Soil Science Society of American Journal 41: 912-915.

Kamalu OJ, Ugwa IK, Omenihu AA (2014) Survey, classification and suitability evaluation of Akwete soils for rubber (Heveabrasiliensis) cultivation in southeastern Nigeria. Acta Agronomica Nigeriana 14: 56-63.

Kavitha C, Sujatha MP (2015) Evaluation of soil fertility status in various agro ecosystems of Thrissur District, Kerala, India. International Journal of Agriculture and Crop Sciences 8: 328338.

Kumar M, Kumar V, Kumar R, Pratap R (2017) Correlation between soil nutrient and plant nutrient concentration in mustard. Journal of Pharmacognosy and Phytochemistry 6: 751 - 754.

Marschner H (1997) Mineral nutrition of higher plants, Academic Press, San Diego.Pp. 889.

Miller PA, Williams JC, Robinson HF, Comstoc RE (1958) Estimates of genotypic and environmental variances and covariance in upland cotton and their implications in selection. Agronomy Journal 50: 126 - 131 .

Mohammadi SA, Prasanna BM (2003) Analysis of genetic diversity in crop plants salient statistical tools and considerations. Crop Science 43:1235-1248.
NageswaraRao DVK, Jose AL (2002) Numerical classification of soils under rubber in Kerala. Journal of Indian Society Soil Science 50: $492-497$.

Nassir A (2002) Studies on genotype x environment interactions, variability and plant character correlation in rice. $\mathrm{PhD}$ thesis submitted to the Postgraduate school of University of Agriculture, Abeokuta, Nigeria Pp. 123.

Nwofia GE, Awaraka R, Mbah EU (2014) Yield and yield component assessment of some African

yam bean genotypes (Sphenostylis stenorcarpa Hochst Ex A. Rich) Harm in low land humid tropics of south eastern Nigeria. American- Eurasian Journal Agricultural and Environmental Sciences 14: 923-931.

Okore IK, Akpobome FA, Tijani-Eniola H, Oghide EA (2007) Effect of tillage on the growth performance of Hevea seedling rootstock and some fertility indices of sandy acid soil in the humid forest area of Nigeria. Journal of Rubber Research 10: 116126.

Okore IK, Idubor C, Ogidi EGO, Okundia RO (2016) Latex and dry rubber yield response of a natural rubber clone to stimulation and fertilizer application in a sandy-loam ultisol. Proceedings of the $3^{\text {rd }}$ National Annual of Conference of crop Society of Nigeria, held at UNN, Nigeria on $27^{\text {th }}-39^{\text {th }}$ September, 2016 Pp. 496-503.

Oku E, Iwara A, Ekukinam E (2012) Effects of age of rubber (Hevea brasiliensis Muell Arg.) plantationon $\mathrm{pH}$, organic carbon, organic matter, nitrogen and micronutrient status of ultisols in the humid forest zone of Nigeria. Kasetsart Journal Natural Science 46: 684-693.

Omokhafe KO, AliKa JE (2000) Multivariate of agronomic data on Heveabrasiliensis. In: NoKoe S (Ed). Biometry and quality of life. Proceedings of SUSAN - IBS meeting, $23^{\text {rd }} 27^{\text {th }}$ August, 1999 , Ibadan, Nigeria, SUSAN - IBS, Nairobi, Kenya, Pp. 168 - 173.

Osayande PE, Oviasogie PO, Awanlemhen BE, Orhue ER (2014) Soil fertility assessment of a Shea (Vitellaria paradoxa Gaertn C. F.) field at Bida, Niger, State. Nigerian Journal of Soil Science $24: 117-124$.

Raji AA (2002) Assessment of genetic diversity and heterotic relationship in African improved and local cassava (Manihot esculentus Crantz) germplasm. $\mathrm{PhD}$ thesis submitted to the Postgraduate school, University of Ibadan, Nigeria.

Samish RM, Gur A (1962) Experiments with budding avocado. Proceedings of the American Society for Horticultural Science 81:194-201. 
SAS Institute Inc. (1996) SAS software: Changes and enhancements through release, 6.12. Cary: SAS Institute Inc.

Snedecor GW, Cochran WG (1980) Statistical methods (Ed. 7). The Iowa State University Press, Ames, Iowa, U.S.A. Pp. 507.

SPSS (2004) SPSS for windows version (16.0) software programme.

Suchartgul S, Maneepong S, Issarakrisila M (2012) Establishment of standard values for nutrient diagnosis in soil and leaves of immature rubber tree. Rubber Thai Journal 1: 19-31.

Tisdale SL, Nelson WL, Beaton JD (1993) Soil Fertility and Fertilizers, 5th Edition, Macmillan Publishing Co., New York U.S.A.
Tolentino LM (2010) Mykovam as a promising organic fertilizer on the growth of rubber (Heveabrasiliensis) seedlings at USM, Kabacan, Cotabato, Philippines. USM R and D Journal18: 125128

Waizah Y, Giroh YD, OjieKpon F, Umar H, Oghide A (2011) Influence of rubber effluent on some soil chemical properties and early growth of rubber seedling. Proceedings of the $45^{\text {th }}$ Annual Conference of Agricultural Society of Nigeria, held at UDUS, Nigeria on $24^{\text {th }}-28^{\text {th }}$ October, 2011 Pp. 469-477.

Wiley EO (1981) Phylogenetics: Theory and Practice of Phylogenetics and Systematics. John Wiley, New York U.S.A.

Yada B, Tuamuhabwa P, Alajo A, Mwanga ROM (2010) Morphological characterization of Ugandan sweet potatogermplasm. Crop Science 50: 2364-2371. 